\title{
HIPERTERMIJOS IR DEHIDRATACIJOS POVEIKIS SUAUGUSIŲ VYRŲ GRIAUČIUU RAUMENŲ NUOVARGIUI ATLIEKANT MAKSIMALAUS INTENSYVUMO IZOMETRINIUS PRATIMUS
}

\author{
Kazys Vadopalas ${ }^{1}$, Albertas Skurvydas ${ }^{1}$, Marius Brazaitis ${ }^{1}$, Pavelas Zachovajevas ${ }^{1}$, \\ Dalia Mickevičiené $\dot{1}^{1}$, Mindaugas Dubosas ${ }^{1,2}$ \\ Lietuvos kūno kultūros akademija ${ }^{l}$, Kauno technologijos universitetas ${ }^{2}$, Kaunas, Lietuva
} Kazys Vadopalas. Lietuvos kūno kultūros akademijos doktorantas. Lietuvos kūno kultūros akademijos Taikomosios fiziologijos ir sveikatos
ugdymo katedros asistentas. Mokslinių tyrimų kryptis — raumenų fiziologija: hipertermijos ir dehidratacijos poveikis raumenų nuovargiui.

\section{SANTRAUKA}

Tyrimo tikslas - nustatyti hipertermijos ir dehidratacijos poveiki maksimaliajai valingai jegai (MVJ) ir centriniam nuovargiui, ¿vertinti, kaip rehidratacija veikia hipertermijos salygomis griaučiu raumenu funkcijas atliekant 2 min maksimalu izometrini krūvi. Tiriamieji - suauge aktyviai nesportuojantys vyrai $(n=10)$. Ju amžius $-22,2 \pm 3,4$ m.,

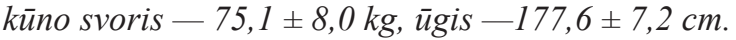

Atlikti trys tyrimai - vienas kontrolinis ir du eksperimentiniai. Vieno eksperimento metu buvo sukeliama organizmo hipertermija ir dehidratacija (tiriamieji 45 min sèdejo panirę iki dubens šiltoje vonioje, kurios vandens temperatüra $-44 \pm 1{ }^{\circ} \mathrm{C}$ ). Kito eksperimento metu ta pačia metodika sukeliant hipertermija buvo atliekama peroraline organizmo rehidratacija $1000 \mathrm{ml} 37^{\circ} \mathrm{C} \mathrm{NaCl} \mathrm{0,9 \%} \mathrm{tirpalu.} \mathrm{Maksimalus} \mathrm{valingos} \mathrm{jègos} \mathrm{(MVJ)} \mathrm{krūvis} \mathrm{tęsèsi} 120 \mathrm{~s}:$ kas 15 s raumuo buvo stimuliuojamas elektros impulsais - stimuliacijos trukme $250 \mathrm{~ms}$, dažnis $100 \mathrm{~Hz}$, itampos dydis 85-105 V. Registruotas raumenu MVJ momentas $(N \cdot m)$ ir raumenu valingo aktyvavimo laipsnis VA\% $=(M V J+e l e k$ trinis impulsas) / MVJ $\times 100$. Tiriamieji krūvio metu buvo motyvuojami verbaliniu būdu, suteikiant jiems vizualujègos signalo kitimo atgalini ryší. Sukèlus hipertermija ir dehidratacija, rektalinè kūno temperatūra vidutiniškai padidèjo пио 37,33 $\pm 0,36$ iki $39,13 \pm 0,25^{\circ} \mathrm{C}(\mathrm{p}<0,001)$, atlikus rehidratacijq hipertermijos sqlygomis - nuo 37,28 $\pm 0,36$ iki 39,22 $\pm 0,4^{\circ} \mathrm{C}(\mathrm{p}<0,001)$. Hipertermijos eksperimento metu tiriamieji vidutiniškai neteko 0,93 $\pm 0,32 \mathrm{~kg}$, ir tai sudare 1,17 \pm 0,4\% kūno svorio ( ${ }^{\circ}$ dehidratacija). Išanalizavus fiziologinį šilumos streso indeksq (10 balu sistema) nustatyta, kad tiriamieji patyre vidutinio ir aukšto lygio fiziologini stresq (hipertermijos atveju - 6,42 $\pm 0,71$, rehidratacijos - 7,16 $\pm 0,91)$. MVJ krūvio pabaigoje visais atvejais sumažejo reikšmingai (p < 0,001), palyginti su prieš krūvį nustatytais rodikliais. Atsigavimo metu, praejjus 15 s po krūvio, jèga grįzo ì pradinį lygị. Dvieju veiksniu dispersiné analize atskleidè, kad analizuojamujègos rodikliu pokytis priklausè nuo laiko ( $<<0,001)$, o hipertermijos dydžio ir sqveikos tarp ju rezultato reikšmingai nepaveikè $(p>0,05)$. Išanalizavus valingo aktyvavimo rodiklius pastebèta, kad hipertermija $(p<0,05)$ ir rehidratacija $(p<0,01)$ reikšmingai padidino raumenu valingo aktyvavimo laipsni VA\%, palyginti su prieš krūvi nustatytu. Atsigavimo metu, praejus 15 s po krūvio, valingo aktyvavimo jẻgos rodiklis buvo toks pat kaip ir prieš krūvi. Atlikus dvieju veiksniu dispersinę analizę nustatyta, kad analizuojamu valingo aktyvavimo jëgos rodikliu pokytis priklausè nuo laiko $(p<0,001)$ ir sqveikos tarp büsenos bei laiko $(p<0,01)$, o būsena rezultato reikšmingai nepaveikè $(p>0,05)$. Taikant pasyvaus raumenu šildymo metodika, sukèlème tiriamuju organizmo hipertermija ir I ${ }^{\circ}$ dehidratacija. Hipertermija padidino centrini nuovargi. Hipertermijos ir rehidratacijos eksperimentu metu MVJ nuovargis kito vienodai. Rehidratacija hipertermijos salygomis neigiamai veike ir dar labiau padidino centrini nuovargi atliekant 2 min maksimalu izometrini krūvi.

Raktažodžiai: hipertermija, izometriniai pratimai, dehidratacija, rehidratacija, centrinis nuovargis.

\section{IVADAS}

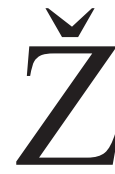
mogaus galimybè atlikti fizini darbą tiesiogiai priklauso nuo kūno vidinès temperatūros svyravimo. Hipertermija - tai simptominis kūno temperatūros padidèjimas iki $38,2^{\circ} \mathrm{C}$ dèl šilumos atidavimo sutrikimo. Padidèjus šerdinei kūno temperatūrai iki kritinès ribos (vidutinio fizinio aktyvumo asmenu $-38,7 \pm 0,2^{\circ} \mathrm{C}$, didelio meistriškumo $-39,2 \pm 0,1^{\circ} \mathrm{C}$ ), žmogaus kūnas perkaista, tada atsiranda nuovargis. Šiam pokyčiui hidratacija ir aklimatizacija ittakos neturi (Cheung, McLellan, 1998). Hipertermija padidina fiziologinę kūno itampą, kurios metu gali smarkiai sumažèti fizinis darbingumas, vedantis prie išsekimo, perkaitimo, traumos ir netgi mirties. Daugelis gyvūnu atsisako fizinès veiklos, kol ju ašinè temperatūra pasiekia saugią ribą. Literatū- 
roje nuolatos keliama hipotezè, kad pavojingai aukšta vidinè kūno temperatūra tiesiogiai padidina nuovargi ir pagreitina išsekimą. Pastaroji tema yra plačiai nagrinejjama, tačiau esminiai mechanizmai nèra iki galo išsiaiškinti (Morrison et al., 2004). Hipertermijos sąlygomis fizinis darbingumas sumažèja dèl ašinès temperatūros padidejjimo iki kritinès ribos (Cheung, McLellan, 1998), kuriai esant suaktyvinamos termoreguliacijos ir širdies kraujagyslių sistemos (Rowell, 1974). Hipertermijos sąlygomis atsiranda periferijos pokyčiuc, padideja raumenų susitraukimo ir atsipalaidavimo greitis (De Ruiter, De Hann, 2000). Hipertermija gali tiesiogiai veikti raumenų valingą aktyvavimą, kadangi temperatūra motoriniame vienete pakeičia impulso dažni, reikalingą tetaniniam susitraukimui (Todd et al., 2004).

Kuri laiką buvo manoma, kad mechanizmas, paaiškinantis neuroraumenini nuovargi, hipertermijos sąlygomis gali kilti tiek dèl centrinès, tiek dèl periferinès nervų sistemos pokyčiu (KentBraun, 1999). Tačiau M. M. Thomas ir ktl. (2006) atliktu tyrimu irodè, kad hipertermija sumažino neuroraumenini darbingumą, ir tai priklausè nuo centrinès nervų sistemos negalèjimo gerai aktyvuoti raumens, o periferijos pokyčiai tam tiesioginès itakos neturejo.

Hipertermijos metu vykstanti temperatūrinè homeostazė didina prakaitavimą ir širdies kraujagysliu sistemos darbą (Armstrong, 2000). Priežastis, dèl kurios gali sumažèti raumenų fizinis darbingumas, yra skysčių netekimas organizme - dehidratacija. Hipertermijos metu netekus $2 \%$ kūno svorio, žmogaus ištvermè sumažeja $22 \%$, o netekus $4 \%$ - net 48\% (Armstrong et al., 1992). Dirbant karšto klimato sąlygomis ar atliekant didelio intensyvumo ilgos trukmès fizinius pratimus, žmogus vidutiniškai netenka $0,8-1,41 / \mathrm{h}$ prakaito (Armstrong, 2000). Didžiausias nustatytas prarandamo prakaito kiekis - 3,7 1/ h (Armstrong, 1986). Aklimatizuoti žmonès kartu su prakaitu netenka apie $0,8-2,0 \mathrm{~g}$ $\mathrm{NaCl} / 1$, o neaklimatizuoti - apie 3,0—4,0 g NaCl / 1 (Armstrong, 2000). Pastarieji elektrolitai žmogaus organizme yra laikomi pagrindiniais, kuriu dèka palaikoma vandens pusiausvyra viduląstelinejje ir tarpląstelinèje terpejje, nervinis laidumas, ląstelinis metabolizmas ir kraujo tūris - osmoreguliacija ir spaudimas (Armstrong, 2000). Maksimalus skysčių kiekis, kuri fiziškai aktyvių žmoniu organizmas gali pasisavinti, yra apie $0,8-1,21 / \mathrm{h}$ (Coyle \& Hamilton, 1990).

Iki šiol literatūroje nepavyko rasti duomenų, irodančių, kokị termini poveiki patiria tiriamieji, kai jiems taikoma A. J. Sergeant (1987) pasiūlyta pasyvaus šildymo metodika. Taip pat neaptikta duomenų, irodančių, kaip per 45 min pasyviai sukelta hipertermija ir dehidratacija veikia raumenu funkcini pajėguma, nèra iki galo aiškus rehidratacijos poveikis hipertermijos sąlygomis, kai atliekami maksimalaus intesyvumo izometriniai pratimai.

Tyrimo tikslas - nustatyti hipertermijos ir dehidratacijos poveiki MVJ ir centriniam nuovargiui, išaiškinti, kaip rehidratacija veikia hipertermijos sąlygomis griaučių raumenu funkcijas atliekant 2 min maksimalų izometrinị krūvị.

\section{TYRIMO METODAI IR ORGANIZAVIMAS}

Tiriamieji - sveiki fiziškai aktyvūs vyrai $(\mathrm{n}=10)$. Jų amžius $-22,2 \pm 3,4$ metų, kūno masè $-75,1 \pm 8,0 \mathrm{~kg}$, ūgis $-177,6 \pm 7,2 \mathrm{~cm}$. Tiriamieji buvo supažindinti su tyrimo tikslais, procedūra ir galimais nepatogumais. Nora dalyvauti tyrime jie patvirtino raštu. Tyrimas atliktas laikantis 1975 m. Helsinkio deklaracijoje priimtu principu dèl eksperimentu su žmonėmis etikos. Tyrimo protokolas aptartas ir patvirtintas Kauno regioniniame biomedicininių tyrimų etikos komitete (Protokolo Nr. 130/2005; Leidimo Nr. BE-2-54).

Dinamometro nustatymas ir padėties sureguliavimas. Izometrinè blauzdos tiesiamuju raumenu jèga vertinta naudojant izokinetini dinamometrą (Biodex Medical System 3, New York). Tiriamieji buvo sodinami i dinamometro įrenginio kèdę, testuojama dešinè koja. Prie dinamometro pritvirtinamas papildomas blauzdos tvirtinimo itaisas. Nustatoma kelio anatominè sąnario ašis ir sulyginama su dinamometro dianaminès apkrovos mazgo ašimi. Nustatoma visa kelio sąnario amplitude (blauzdą ištiesus $0^{\circ}$ ir sulenkus $115^{\circ} \mathrm{kampu}$ ). Mažinant viso kūno inercinị svyravimą, tiriamasis apjuosiamas pečių, liemens ir šlaunies diržais. Blauzda sutvirtinama diržu virš kulnakaulio gumburo ties apatiniu trečdaliu, koja fiksuojama per kelio sąnari 90 ir $60^{\circ} \mathrm{kampu}$, pasveriama tada, kai ji fiksuota $72 \pm 5^{\circ} \mathrm{kampu}$ (gravitacinès sunkio jègos momentu). Valdymo skyde pasirenkamas izometrinis režimas. Registruota maksimalioji valinga raumenų susitraukimo jèga.

Eksperimento logika. Prieš eksperimentą buvo atliekamas žvalgomasis tyrimas, kurio metu tiriamieji turejo priprasti prie laboratorijos aplinkos sąlygų ir pasimokyti atlikti didžiausio valingo 
izometrinio susitraukimo krūvị. Ne anksčiau kaip po savaitès tiriamieji, atrinkti atsitiktiniu būdu, atliko kontrolini arba vieną iš eksperimentiniu tyrimu.

Atlikti trys tyrimai — vienas kontrolinis ir du eksperimentiniai. Kontrolinio tyrimo metu tiriamieji po neintensyvios pramankštos - 10 min bègimo (pulso dažnis - 110 - 130 tv. / min) — buvo sodinami i specialią izokinetinio dinamometro kèdę ir atliko testavimą pagal tą pati protokolą, tik pasyviai raumenų nešildant.

Pirmas eksperimentinis tyrimas nuo kontrolinio skyrèsi tuo, kad jo metu vietoj pramankštos buvo pasyviai sukeliama hipertermija. Antro eksperimento metu ta pačia metodika sukeliant hipertermija, buvo atliekama peroralinè organizmo rehidratacija $1000 \mathrm{ml} 37^{\circ} \mathrm{C}$ (kūno temperatūros) fiziologiniu $\mathrm{NaCl}$ 0,9\% tirpalu.

Taikant pasyvaus šildymo metodiką, tiriamieji, atvykę i laboratoriją, $30 \mathrm{~min}$ ramiai sédèdavo iprastinès temperatūros kambaryje $\left(20-22^{\circ} \mathrm{C}\right)$. Paskui buvo matuojama jų rektalinè temperatūra. Vèliau atliekamas kontrolinis MVJ matavimas, t. y. darant 2 min pertrauką atlikti trys maksimalūs valingi raumens susitraukimai tiesiant blauzda per kelio sąnari $120^{\circ}$ fiksuotu kampu (raumens susitraukimo trukmè - $5 \mathrm{~s}$ ). Maždaug 2-3 susitraukimų sekundę keturgalvis šlaunies raumuo buvo stimuliuojamas $100 \mathrm{~Hz}$ dažnio ir $250 \mathrm{~ms}$ trukmès elektrinių impulsų serija. Paskui kojos buvo šildomos pasyviai, iš karto po šildymo vèl matuojama rektalinè temperatūra. Išlipus iš vonios, ne vèliau kaip po $5 \mathrm{~min}$, tiriamasis buvo sodinamas $i$ specialią dinamometro kẻdę ir turèjo atlikti $2 \mathrm{~min}$ trukmès maksimalaus valingo izometrinio raumens susitraukimo krūvi (MVJ - 2 min). Praėjus 15 ir $300 \mathrm{~s}$ po krūvio, buvo atliekamas kontrolinis testavimas. Krūvio metu tiriamasis vilkejjo šilta ilgą sportinę aprangą, buvo užsidèjęs pirties kepurę (hipertermijai išlaikyti eksperimentiniu tyrimų metu). Abiejų eksperimentų pabaigoje buvo matuojama rektalinè temperatūra (hipertermijai kontroliuoti).

MVJ - 2 min. Maksimalus valingas izometrinis krūvis truko $120 \mathrm{~s}$. Kas 15 s per odą elektriniu impulsu buvo stimuliuojamas šlaunies nervas, naudojant aukštos itampos stimuliatoriu (modelis MG440, Medicor, Budapest, Hungry). Stimuliacijos trukmè $-250 \mathrm{~ms}$, dažnis $-100 \mathrm{~Hz}$, įtampos dydis - 85-105 V. Itampos dydis buvo parenkamas individualiai kiekvienam tiriamajam. Elektrinio impulso itampa didinama tol, kol nevalinga raumenų izometrinio susitraukimo jèga pasiekdavo
$70-75 \%$ maksimaliosios jègos (stimuliacijos trukmè - $1 \mathrm{~s}$, dažnis - $100 \mathrm{~Hz}$ ) (Nybo, Nielsen, 2001). Registruotas maksimaliosios valingos jègos momentas $(\mathrm{N} \cdot \mathrm{m})$ ir raumenu valingo aktyvavimo laipsnis $\mathrm{VA} \%=(\mathrm{MVJ}+$ elektrinis impulsas $) /$ MVJ $\times 100$ (kuo mažesnis VA\%, tuo centrinis nuovargis didesnis $(100 \%$ rodo visišką raumenu aktyvaciją)). Tiriamasis krūvio metu buvo motyvuojamas verbaliniu būdu, suteikiant jam vizualią jègos signalo kitimo informacija.

Pasyvaus šildymo metodika. Tiriamieji sèdẻdami 45 min laikè kojas šiltoje vonioje, kurios vandens temperatūra $-44 \pm 1{ }^{\circ} \mathrm{C}$, kambario temperatūra $20-22^{\circ} \mathrm{C}$. Šildymo metu jie negalejo vartoti jokiu gèrimu ar naudoti dirbtinio vèsinimo irenginių. Šildymo pabaigoje testuojamo raumens temperatūra $3 \mathrm{~cm}$ gylyje padidèja $\sim 2,7^{\circ} \mathrm{C}$ (Sargeant, 1987). Vandens temperatūra buvo matuojama vandens termometru, patalpos - oro termometru.

Rektalinès temperatūros matavimo metodika. Rektalinè temperatūra buvo matuojama zondu, apvilktu silikonine guma su imontuotu termodavikliu (Ellab, tipas Rectal probe, Danija). Tiriamasis prieš ir po pasyvaus šildymo įsikišdavo zondą su termodavikliu i išeinamają angą (laikas $-10 \mathrm{~s}$, gylis $-12 \mathrm{~cm}$ ) (Proulx, 2003). Zondas su termodavikliu po panaudojimo buvo sterilizuojamas autoklave.

Širdies ir kraujagyslių sistemos būsenos vertinimas. Pasyvaus šildymo metu širdies susitraukimų dažnis buvo registruojamas $5 \mathrm{~s}$ intervalais pulso matuokliu „Polar 625 x“ (Suomija).

Fiziologinio streso (šilumos) indekso (FSI) matavimo metodika. FSI buvo apskaičiuotas pagal formulę (Moran et al., 1998):

FSI $=5\left(T_{\text {rektalinet } t}-T_{\text {rektaline e }}\right) \times\left(39.5-T_{\text {rektaline } 0}\right)^{-1}+\left(\check{S S D}_{t}-\check{S S S D}_{0}\right) \times\left(180-\check{S} S D_{0}\right)$,

čia - $\mathrm{T}_{\text {rektalinè } 0}$ ir $\mathrm{S} S D_{0}$ - pradiniai matavimai; $\mathrm{T}_{\text {rektalinè t }}$ ir ŠSD

FSI vertinimas - streso nèra arba labai mažas $(0-2$ balai); žemas ( $3-4$ balai); vidutinis ( $5-6$ balai); aukštas $(7-8$ balai) ir labai aukštas (9-10 balų).

Rehidratacija. Nustatyta, kad hipertermijos metu žmogaus organizmas vidutiniškai netenka $0,8-1,41$ prakaito, kur viename litre randama nuo 0,8 iki $4 \mathrm{~g} \mathrm{NaCl}$. Žmogaus organizmas per valandą gali pasisavinti apie $0,8-1,21$ skysčiu (Armstrong et al., 1986; Armstrong, 2000). Norint atgauti prarastą skystí, tiriamiesiems 15 min prieš pasyvu šildymą buvo duodama gerti fiziologinio $(0,9 \% \mathrm{NaCl}) 37^{\circ} \mathrm{C}$ (kūno temperatūros) tirpalo. Per $60 \mathrm{~min}$ tiriamieji lètai išgerdavo $1000 \mathrm{ml}$ skysčio 
(po $100 \mathrm{ml}$ kas $6 \mathrm{~min}$ ). Prieš tyrimą ir po jo nuogi vyrai (sausu kūnu) buvo sveriami elektroninèmis svarstyklèmis „Tanita TBF 300“(Jungtinès Amerikos Valstijos). Nustatytas svorio skirtumas parode skysčių kiekį, kurio neteko tiriamasis. Tiriamieji laikotarpiu tarp svèrimų negalèjo šlapintis ir vartoti skysčių.

Matematinė statistika. Buvo apskaičiuojami rodiklių aritmetiniai vidurkiai ir standartiniai nuokrypiai. Širdies ir kraujagyslių sistemos rodikliu ( $\breve{S} \mathrm{SD}, \mathrm{AKS}$ ) kaitos priklausomumas nuo hipertermijos ir laiko buvo analizuojamas naudojant dviejų veiksnių dispersinę analizę. Skirtumo tarp aritmetinių vidurkių reikšmingumas nustatytas pagal dvipusi nepriklausomų imčių Stjudento $t$ kriterijų. Skirtumas statistiškai reikšmingas, kai $\mathrm{p}<0,05$.

\section{REZULTATAI}

Sukèlus hipertermiją ir dehidrataciją, rektalinè kūno temperatūra vidutiniškai padidejo nuo $37,33 \pm 0,36$ iki $39,13 \pm 0,25^{\circ} \mathrm{C}(\mathrm{p}<0,001)$, atlikus rehidrataciją hipertermijos sąlygomis - nuo $37,28 \pm 0,36$ iki $39,22 \pm 0,4^{\circ} \mathrm{C}(\mathrm{p}<0,001)$. Reikšmingo skirtumo tarp vertinamų būsenų nenustatyta $(p>0,05)$. Hipertermijos eksperimento metu tiriamieji vidutiniškai neteko $0,93 \pm 0,32 \mathrm{~kg}$, ir tai sudare $1,17 \pm 0,4 \%$ kūno svorio ( $\mathrm{I}^{\circ}$ dehidratacija). Atlikus peroralinę rehidrataciją hipertermijos sąlygomis, tiriamuju kūno svoris vidutiniškai padidèjo $0,13 \pm 0,33 \mathrm{~kg}$, ir tai sudarè $0,17 \pm 0,43 \%$ jų kūno svorio. Pastarieji rodikliai rodo, kad organizmo rehidratacija buvo atlikta iki galo. Išanalizavus fiziologini karščio streso indeksą (10 balų sistema) nustatyta, kad tiriamieji patyrè vidutinio ir aukšto lygio fiziologini stresą: hipertermijos tyrimo metu $-6,42 \pm 0,71$, rehidratacijos $-7,16 \pm 0,91$. Reikšmingai patikimo skirtumo tarp vertinamų būsenų rodiklių nenustatyta $(\mathrm{p}>0,05)$.

MVJ krūvio pabaigoje visų tyrimų metu sumažèjo reikšmingai $(p<0,001)$, palyginti su prieš krūvi nustatytais rodikliais (1 pav.). Raumenu izometrinio susitraukimo jèga labiausiai sumažèjo hipertermijos ir rehidratacijos eksperimento metu, palyginti su kontroline reikšme. Atsigavimo metu, praejus $15 \mathrm{~s}$ po krūvio, MVJ buvo tokia pat kaip ir prieš krūvị. Dviejų veiksnių dispersinè analizė atskleide, kad analizuojamu jègos rodikliu pokytis priklausè nuo laiko $(\mathrm{p}<0,001)$, o hipertermijos dydžio ir sąveikos tarp jų rezultato reikšmingai nepaveikè $(p>0,05)$.
Išanalizavus valingo aktyvavimo rodiklius pastebèta, kad hipertermija $(\mathrm{p}<0,05)$ ir rehidratacija $(\mathrm{p}<0,01)$ reikšmingai padidino raumenu valingo aktyvavimo laipsni (VA\%), palyginti su prieš krūvị nustatytu (2 pav.). Svarbu paminèti, kad rehidratacija hipertermijos sąlygomis neturejo itakos MVJ - 2 min nuovargiui ir atsigavimui, lyginant su hipertermijos eksperimentu, tačiau pastebètas didesnis valingo aktyvavimo laipsnis, t. y. buvo sukeltas centrinis nuovargis. Atsigavimo metu, praejjus $15 \mathrm{~s}$ po krūvio, valingo aktyvumo rodiklis grį̌o iki prieš krūvị nustatyto rodiklio dydžio. Atlikus dviejų veiksnių dispersinę analizę nustatyta, kad analizuojamų valingo aktyvavimo rodiklių pokytis priklausé nuo laiko $(\mathrm{p}<0,001)$ ir sąveikos tarp būsenos ir laiko ( $\mathrm{p}<0,01)$, o būsena rezultato reikšmingai nepaveikè $(\mathrm{p}>0,05)$.

\section{REZULTATŲ APTARIMAS}

Iki šiol literatūroje nepavyko aptikti duomenų, irodančių, koki termini poveiki patiria tiriamieji, kai jiems taikoma A. J. Sergeant (1987) pasyvaus raumenu šildymo metodika. Panašia metodika hipertermijos eksperimento metu ir mes sukèlème organizmo hipertermiją (rektalinè kūno temperatūra vidutiniškai padidejjo nuo $37,33 \pm 0,36$ iki $39,13 \pm 0,25^{\circ} \mathrm{C}(\mathrm{p}<0,001)$, padidejjo šiluminio streso indeksas FSI) ir $\mathrm{I}^{\circ}$ dehidrataciją (skysčiu netekta iki $2 \%$ kūno svorio).

Taip pat neradome duomenų, irodančių, kaip per 45 min pasyviai sukelta hipertermija ir dehidratacija veikia raumenu funkcini pajègumą. Padidejus ašinei kūno temperatūrai iki $38,7^{\circ} \mathrm{C}$ (vidutinio fizinio aktyvumo asmenu) ar $39,2^{\circ} \mathrm{C}$ (didelio meistriškumo asmenų), žmogus patiria kūno perkaitimą, atsiranda nuovargis (Cheung, McLellan, 1998). Hipertermijos eksperimento metu nustatyta, kad hipertermija ir dehidratacija padidino maksimaliosios valingosios jègos nuovargi atliekant MVJ-2 min ir nustatytas didesnis valingo aktyvavimo laipsnis, t. y. atsirado didesnis centrinis nuovargis, palyginti su kontrolinio tyrimo duomenimis. Galima manyti, kad labai staigus šerdinès kūno temperatūros padidejjimas ir prakaito netekimas taip pat galejo turèti itakos galutiniams tyrimo rezultatams.

Mokslininkai naudojosi įvairiais pasyvaus šildymo ir rehidratacijos metodais (rektalinè temperatūra iki $39,5^{\circ} \mathrm{C}$ buvo pasiekiama per $110 \mathrm{~min}$, tiriamieji suvartodavo apie 1,4 1 skysčiu (Thomas et al., 2006)). Kol kas nèra aišku, kaip rehidratacija hipertermijos salygomis veikia MVJ ir centrini 

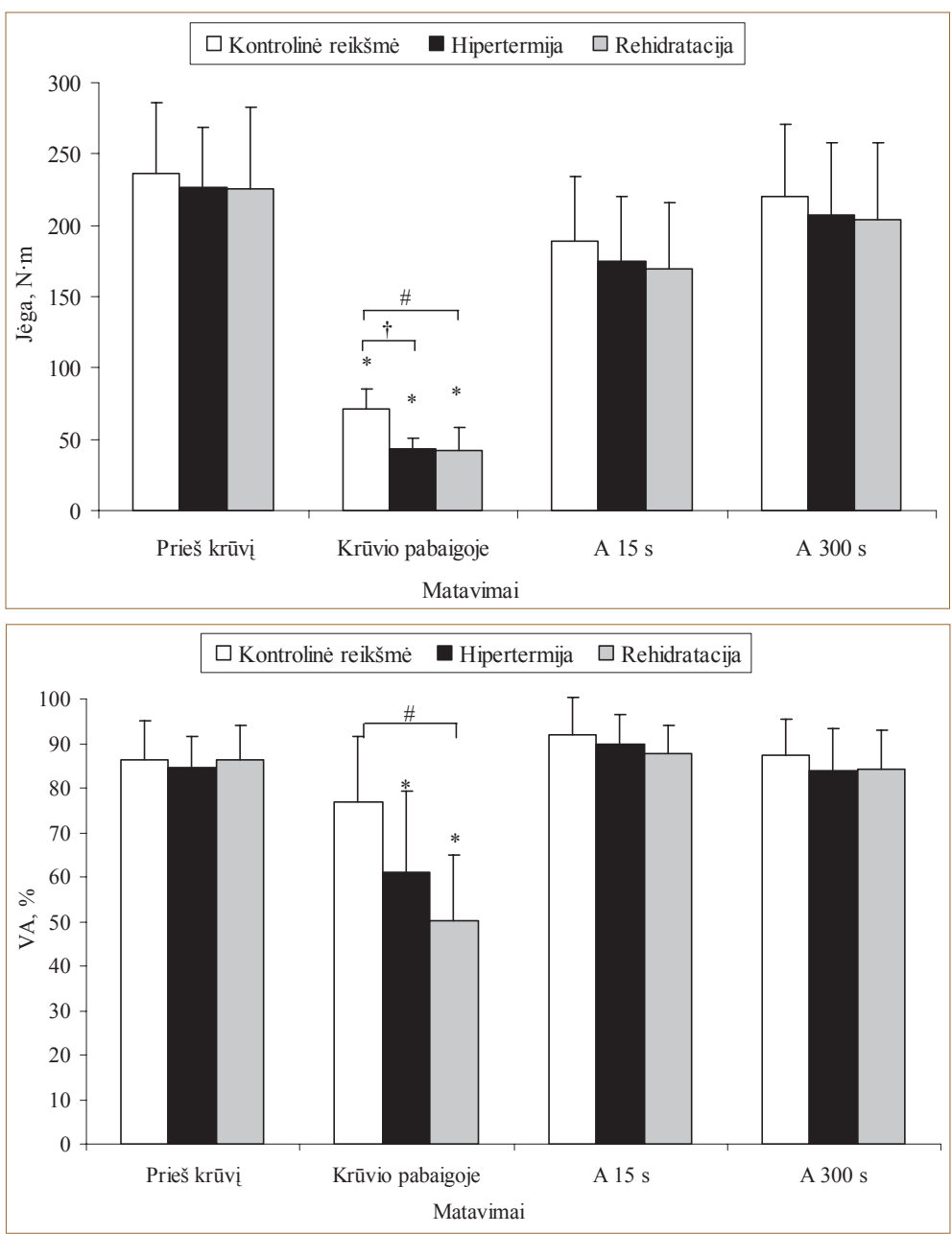

1 pav. Maksimaliosios valingos jègos rodikliai atliekant MVJ-2 min — tiesiant blauzdą per kelio sąnarị fiksuotu $120^{\circ} \mathrm{kampu}$
Pastaba. \# - skirtumas tarp kontrolinès reikšmès ir rehidratacijos rodikliu $(\mathrm{p}<0,05)$; † - skirtumas tarp kontrolinès reikšmės ir hipertermijos rodikliu $(\mathrm{p}<0,05) ; *$ - pokytis, palyginti su pradine reikšme $(\mathrm{p}<0,05)$.

2 pav. Valingo aktyvavimo rodikliai atliekant MVJ2 min - tiesiant blauzdą per kelio sąnarị fiksuotu $120^{\circ}$ kampu
Pastaba. \# - skirtumas tarp kontrolinès reikšmės ir rehidratacijos rodikliu $(\mathrm{p}<0,05)$; * pokytis, palyginti su pradine reikšme $(\mathrm{p}<0,05)$. nuovargi, kuris dažnai pastebimas atliekant maksimalaus intensyvumo izometrinius pratimus.

Rehidratacijos eksperimento metu netektam skysčiui atgauti tiriamieji gèrè fiziologini ( $0,9 \%$ $\mathrm{NaCl}) 37^{\circ} \mathrm{C}$ (kūno temperatūros) tirpalą. Atlikus peroralinę rehidrataciją hipertermijos sąlygomis, tiriamujuc kūno svoris vidutiniškai padidèjo $0,13 \pm 0,33 \mathrm{~kg}$, ir tai sudarè $0,17 \pm 0,43 \%$ jų kūno svorio. Tai rodo, kad tiriamieji iki maksimalaus krūvio pradžios visiškai atgavo iš organizmo pašalinto skysčio kieki.

Šio eksperimento metu nustatyta, kad rehidratacija hipertermijos sąlygomis neturèjo itakos MVJ nuovargiui ir atsigavimui, palyginti su hipertermijos eksperimentu, tačiau nustatytas didesnis valingo aktyvavimo laipsnis, t. y. sukeltas didesnis centrinis nuovargis atliekant MVJ-2 min. Galima manyti, kad tai iš dalies priklauso nuo fiziologinio $\mathrm{NaCl} 0,9 \% 37^{\circ} \mathrm{C}$ temperatūros tirpalo temperatūros, jo patekimo ì kraujotakos sistemą biocheminių mechanizmų pokyčių, skysčių rezorbcijai panaudotos energijos sunaudojimo. Dèl peroralinès rehidratacijos galejo pakisti natrio ir kalio pusiausvyra viduląstelinèje ir tarpląstelinejje terpèje. Pastarieji elektrolitai žmogaus organizme yra laikomi pagrindiniais, kurių dėka palaikoma vandens pusiausvyra viduląstelinèje bei tarpląstelinèje terpèje, nervinis laidumas, ląstelinis metabolizmas ir kraujo tūris - osmoreguliacija ir spaudimas (Armstrong, 2000). Dèl to dar labiau padideja fiziologinis terminis stresas ir centrinis nuovargis.

Gauti rezultatai sutampa su kitų mokslininku gautaisiais, irodančiais, kad hipertermija sumažina valinga jègą ir padidina valingo aktyvavimo laipsnị atliekant ištvermès reikalaujančius fizinius pratimus. L. Nybo ir B. Nielsen (2001) tyrimu irodè, kad hipertermijos metu (rektalinè temperatūra $\sim 39,7^{\circ} \mathrm{C}$ ) $\mathrm{MVJ}$ izometrinè raumenu jèga po $2 \mathrm{~min}$ nenutrūkstamo krūvio sumažèjo 58\%, o valingo aktyvavimo laipsnis - 54\%, palyginti su kontroline reikšme. Šio tyrimo metu krūvio pabaigoje MVJ izometrinè raumenų jèga sumažèjo 60\%, valingo aktyvavimo laipsnis — 86\%, palyginti su kontroline reikšme.

Galima manyti, kad fiziologinio terminio streso atsaką lemia daugybè veiksnių, tarp kurių neabejotinai yra skysčiu pasisavinimo fiziologiniai mechanizmai ir pasyvaus šildymo metodikos parinkimas. 


\section{IŠVADOS}

1. Taikant pasyvaus raumenu šildymo metodika, buvo sukelta tiriamujų organizmo hipertermija ir $I^{\circ}$ dehidratacija.
2. Hipertermijos ir rehidratacijos eksperimentų metu MVJ nuovargis kito vienodai.

3. Hipertermija padidino centrini nuovargi.

4. Rehidratacija hipertermijos sąlygomis turejjo neigiamos itakos ir dar labiau padidino centrini nuovargi.

\section{LITERATŪRA}

Armstrong, L. E., Curtis, W. C., Hubbard, R. W. et al. (1992). Symptomatic hyponatremia during prolonged exercise in heat. Medicine \& Science in Sport \& Exircise, $25,543-549$.

Armstrong, L. E., Hubbard, R. W., Jones, B. H., Daniels, J. T. (1986). Preparing Alberto Salazar for the heat of the 1984 Olympic marathon. The Physician and Sport Medicine, 14, 73-81.

Armstrong, L. E. (2000). Performing in extreme environments: The importance of dietary sodium. Human Kinetics, 38-45.

Cheung, S. S., McLellan, T. M. (1998). Comparison of short-term aerobic training and high aerobic power on tolerance to uncompensable heat stress. Aviation, Space, and Environmental Medicine, 70 (7), 637-643.

Coyle, E. F. \& Hamilton, M. A. (1990). Fluid replacment during exercise: Effects on physiological homeostasis and performance. In: C. V. Gisolfi \& D. R. Lamb (Eds.), Fluid Homeostasis During Exercise. Perspectives in Exercise Science and Sports Medicine, Vol. 3, 281-308. Carmel, IN: Benchmark Press.

Kent-Braun, J. A. (1999). Central and peripheral contributions to muscle fatigue in humans during sustained maxinal effort. European Journal of Applied Physiology, $80,57-63$.

Moran, D. S., Shitzer, A., Pandolf, K. B., (1998). A physiological strain index to evaluate heat stress. Ambient Journal of Physiology, 275, R 129-134.
Nybo, L., Nielsen, B. (2001). Hyperthermia and central fatigue during prolonged exercise in human. Journal of Applied Physiology, 91, 1055-1060.

Proulx, C. I., Ducharme, M. B., Kenny, G. P. (2003). Effect of water temperature on cooling efficiency during Hyperthermia in humans. Journal of Applied Physiology, 94, 1317-1323.

Rowell, L. B. (1974). Human cardiovascular adjustments to exercise and thermal stress. Physiological Review, 54, $75-159$.

De Ruiter, C. J., De Haan, A. (2000). Temperature effect on the force / velocity relationship of the fresh and fatigued human adductor pollicis muscle. European Journal of Physiology, 440, 163-170.

Sargeant, A. J. (1987). Effect of muscle on leg extension force and short-term power output in humans. European Journal of Applied Physiology, 56, 693-698.

Thomas, M. M., Cheung, S. S., Elder, G. C., Sleivert, G. G. (2006). Voluntary muscle activation is impaired by core temperature rather than local muscle temperature. Journal of Applied Physiology, 100, 1361-1369.

Tood, G., Butler, J. E., Taylor, J. L., Gandevia, S. C. (2004). Hyperthermia: a failure of the motor cortex and the muscle. Journal of Physiology, 563 (2), 621-631. 


\title{
IMPACT OF HYPERTHERMIA AND DEHYDRATION ON THE SKELETAL MUSCLE FATIGUE OF MEN PERFORMING ISOMETRIC EXERCICES OF MAXIMUM INTENSITY
}

\author{
Kazys Vadopalas $^{1}$, Albertas Skurvydas ${ }^{1}$, Marius Brazaitis ${ }^{1}$, Pavelas Zachovajevas ${ }^{1}$, \\ Dalia Mickevičienė, ${ }^{1}$ Mindaugas Dubosas ${ }^{1,2}$ \\ Lithuanian Academy of Physical Education', Kaunas University of Technology,
} Kaunas, Lithuania

\begin{abstract}
The aim of the study was to establish the impact of hyperthermia and dehydration and to evaluate the impact of rehydration on the functions of skeletal muscles performing 2 min maximum intensity isometric load under the conditions of hyperthermia. The research participants were male adults not actively engaged in sports $(\mathrm{n}=10)$, aged $22.4 \pm 3.4$ years, with body mass of $75.1 \pm 8.0 \mathrm{~kg}$, and height $-177.6 \pm 7.2 \mathrm{~cm}$.

Three studies were carried out - one control study and the other two - experimental. During the first experiment the bodies of the research participants experienced hyperthermia and dehydration (research participants kept their legs up to the pelvis in the bath with hot water $\left(44 \pm 1^{\circ} \mathrm{C}\right)$ for 45 minutes). During the other experiment, using the same methods of increasing hyperthermia, the organisms experienced peroral rehydration with the $1000 \mathrm{ml}$ solution of $37^{\circ} \mathrm{C} \mathrm{NaCl} 0.9 \%$. The load of maximum voluntary strength (MVS) lasted for 120 seconds, every 15 seconds the muscle was stimulated by electrical impulses - the duration of the stimulation was $250 \mathrm{~ms}$, the frequency was $100 \mathrm{~Hz}$, and the voltage was $85-105 \mathrm{~V}$. We registered the moment of MVS $\left(\mathrm{N}^{*} \mathrm{~m}\right)$ and the degree of voluntary activation of muscles VA\% $=(\mathrm{MVS}+$ electrical impulse $) / \mathrm{MVS} \times 100$. When the load was applied the research participants were motivated verbally, and they were provided with the visual feedback of changes in strength signals. After hyperthermia and dehydration was applied, the rectal body temperature averagely increased from $37.33 \pm 0.36$ to $39.13 \pm 0.25^{\circ} \mathrm{C}(\mathrm{p}<0.00)$, applying rehydration under the conditions of hyperthermia it was from $37.28 \pm 0.36$ to $39.22 \pm 0.4^{\circ} \mathrm{C}(\mathrm{p}<0.001)$. During the hyperthermia experiment the research participants lost $0.93 \pm 0.32 \mathrm{~kg}$ on average, and that was $1.17 \pm 0.4 \%$ of their body mass ( $\mathrm{I}^{\mathrm{o}}$ dehydration). Having analyzed the physiological index of heat stress (in the 10 point system) we established that the research participants experienced average and high level physiological stress - in the case of hyperthermia it was $6.42 \pm 0.71$, and in the case of rehydration $-7.16 \pm 0.91$. At the end of the load the MVS decreased significantly in all the cases $(p<0.001)$, compared to the indices which were established before the load. After 15 seconds during the recovery time the strength regained the level witch was established before the load was applied. Two-factor dispersion analysis revealed that the changes in the analyzed strength indices depended on time $(\mathrm{p}<0.001)$; however, the level of hyperthermia and their interaction did no impact the results $(\mathrm{p}>0.05)$. After the analysis of the indices of voluntary activation we noticed that hyperthermia $(\mathrm{p}<0.05)$ and rehydration $(\mathrm{p}<0.01)$ significantly increased the degree of voluntary activation VA\% compared to the one established before the load. During the recovery time, 15 seconds after the application of the load, the strength index of voluntary activation regained the level which was before the load. The two-factor dispersion analysis allowed us to establish that the changes in the strength indices of voluntary activation depended on time $(\mathrm{p}<0.001)$, the interaction between the condition and time $(\mathrm{p}<0.01)$, and the condition did not significantly affect the result $(\mathrm{p}>0.05)$. Applying the methods of passive heating of muscles the research participants were made to experience hyperthermia and $\mathrm{I}^{\circ}$ dehydration. Hypertension increased the central fatigue. During the experiments of hyperthermia and dehydration MVS fatigue altered at the same level. Under the conditions of hyperthermia rehydration had a negative impact on the central fatigue and increased it even more when the 2 min maximum isometric load was performed.
\end{abstract}

Keywords: hyperthermia, isometric exercises, dehydration, rehydration, central fatigue.

Gauta $2007 \mathrm{~m}$. vasario $13 \mathrm{~d}$.

Received on February 13, 2007

Priimta 2007 m. balandžio 24 d.

Accepted on April 24, 2007
Kazys Vadopalas

Lithuanian Academy of Physical Education

(Lietuvos kūno kultūros akademija)

Sporto g. 6, LT-44221 Kaunas

Lithuania (Lietuva)

Tel +370 37302677

E-mailkazysvado@yahoo.com 